\title{
Biomonitoring of complex occupational exposures to carcinogens: The case of sewage workers in Paris
}

\author{
Hamzeh Al Zabadi ${ }^{1}$, Luc Ferrari*1,2, Anne-Marie Laurent ${ }^{3}$, Aziz Tiberguent ${ }^{4}$, \\ Christophe Paris ${ }^{1}$ and Denis Zmirou-Navier ${ }^{1}$
}

\begin{abstract}
Address: ${ }^{1}$ INSERM-ERI 11, Nancy University Medical School, 9 av de la Forêt de Haye, BP 184, 54505 Vandoeuvre-les-Nancy Cedex, France, ${ }^{2}$ Faculty of Pharmacy of Nancy, 5 rue Albert Lebrun, 54000 Nancy, France, ${ }^{3}$ Hygiene Laboratory of the City of Paris, 11, rue George Eastman, 75013 Paris, France and ${ }^{4}$ Department of Occupational Medicine, Municipality of Paris, 44 rue Charles Moureu, 75013 Paris, France

Email: Hamzeh Al Zabadi - hamzeh.alzabadi@nancy.inserm.fr; Luc Ferrari* - luc.ferrari@pharma.uhp-nancy.fr; Anne-Marie Laurent - annemarie.laurent@paris.fr; Aziz Tiberguent - aziz.tiberguent@paris.fr; Christophe Paris - christophe.paris@nancy.inserm.fr; Denis ZmirouNavier - denis.zmirou@nancy.inserm.fr

* Corresponding author
\end{abstract}

Published: 6 March 2008

BMC Cancer 2008, 8:67 doi:10.1/86/147|-2407-8-67
Received: 27 November 2007

Accepted: 6 March 2008

This article is available from: http://www.biomedcentral.com/I47/-2407/8/67

(C) 2008 Al Zabadi et al; licensee BioMed Central Ltd.

This is an Open Access article distributed under the terms of the Creative Commons Attribution License (http://creativecommons.org/licenses/by/2.0), which permits unrestricted use, distribution, and reproduction in any medium, provided the original work is properly cited.

\begin{abstract}
Background: Sewage workers provide an essential service in the protection of public and environmental health. However, they are exposed to varied mixtures of chemicals; some are known or suspected to be genotoxics or carcinogens. Thus, trying to relate adverse outcomes to single toxicant is inappropriate. We aim to investigate if sewage workers are at increased carcinogenic risk as evaluated by biomarkers of exposure and early biological effects.
\end{abstract}

Methods/design: This cross sectional study will compare exposed sewage workers to nonexposed office workers. Both are voluntaries from Paris municipality, males, aged (20-60) years, non-smokers since at least six months, with no history of chronic or recent illness, and have similar socioeconomic status. After at least 3 days of consecutive work, blood sample and a 24-hour urine will be collected. A caffeine test will be performed, by administering coffee and collecting urines three hours after. Subjects will fill in self-administered questionnaires; one covering the professional and lifestyle habits while the a second one is alimentary. The blood sample will be used to assess DNA adducts in peripheral lymphocytes. The 24-hour urine to assess urinary 8-oxo-7, 8-dihydro2 '-deoxy-Guanosine (8-oxo-dG), and the in vitro genotoxicity tests (comet and micronucleus) using HeLa S3 or HepG2 cells. In parallel, occupational air sampling will be conducted for some Polycyclic Aromatic Hydrocarbons and Volatile Organic Compounds. A weekly sampling chronology at the offices of occupational medicine in Paris city during the regular medical visits will be followed. This protocol has been accepted by the French Est III Ethical Comitee with the number 2007-A00685-48.

Discussion: Biomarkers of exposure and of early biological effects may help overcome the limitations of environmental exposure assessment in very complex occupational or environmental settings. 


\section{Background}

Sewage workers provide an essential service in the protection of public and environmental health. In large cities, sewage is composed of organic residues but also incorporate a wide variety of chemicals produced by roadways scrubbing by rain, water from office and industrial facilities, domestic activities (remainders of painting, drugs, pesticides used indoor, etc). As a result of their contact with wastes, sewage workers are exposed to complex mixtures of toxicants including pathogens, heavy metals, chlorinated organic solvents like chloroform, dichloroethane, perchloroethanol, other solvents (benzene, toluene), aldehydes, nitrosamines, pesticides, dyes, polychlorobiphenyls, and polycyclic aromatic hydrocarbons (PAH) [1-3]. Many of these compounds are known or suspected to be genotoxics and/or carcinogens [4-6], which suggests that those workers may be subject to elevated risk of cancer.

Previous studies have indicated an increase in the incidence of cancer among sewage workers [7-10]. Analyses on specific cancer sites have reported excess numbers of laryngeal, primary liver cancer $[8,10]$, cancer of the prostate gland, nose and nasal sinuses cancers, stomach [9], central nervous system [11], and bladder cancers [12]. However, these data exhibit conflicting results $[8,9]$. A more recent mortality study among the sewage workers of Paris published in 2006 assessed their cause-specific mortality from 1970 until 1999 [7]. A slight but significant excess in mortality was found (SMR $=1.25,95 \% \mathrm{CI} ; 1.15-$ $1.36)$ in particular from cancer mortality $(\mathrm{SMR}=1.37$, 95\% CI; 1.20-1.56), with a suggested excess for oesophagus, liver, pleura and the brain cancers albeit not significant. However, this study didn't measure personal or workplace exposures; it used only qualitative information gathered by a questionnaire and the computerized register of the employees.

As exposure of sewage workers implies contact with multiple potent genotoxics at varying levels (by concentration, time and location) and routes of exposure (by inhalation, dermal and ingestion) [9], characterizing and quantifying it are extremely difficult, and trying to relate adverse outcomes to single toxicant is inappropriate. However, usage of biomarkers to study the association between exposure and early biological genotoxics effects seems more relevant in this setting [5]. These findings may explain that previous studies among sewage workers exhibited conflicting results; some were biased by many confounding factors; others relied on qualitative and/or a questionnaire data; while others used urine or blood samples to evaluate the exposure without workplace measurements. However, sewage workers might be exposed to many agents that may interact with one another resulting in an immeasurable amount of different chemicals.
Rather than trying to describe this immense array of exposures or pursuing the goal to relate the biological health outcomes to specific compound, it might be more reasonable to look for unspecific early effects. Further, changes in the composition of the sewage system over-time may affect the level and character of worker's exposure longitudinally. Thus, assessment of genotoxics at only one point in time may not represent long term occurrence of these substances in the body [13]. However, workplace environment sampling at various locations over-time when the biological specimens were taken might be more representable and would further support the link between occupational sewage exposure and the appearance of genotoxics in both sample types (urine and blood).

In order to precise/assess such exposures to genotoxics/ carcinogens compounds, urine genotoxicity has been widely used as a noninvasive method to evaluate recent exposure among populations exposed to environmental and/or workplace-related complex mixtures of chemicals [14-16]. In Vitro comet [14] and micronucleus [17] assays are among the most widely-used biomarkers of urine genotoxicity for monitoring the risk of DNA damage that stems from occupational and environmental exposures to genotoxics. Comet assay is a sensitive technique, can detect DNA damage in terms of double and single-strand breaks, and alkaline-labile sites $[18,19]$. Micronucleus test is a reliable biomarker of irregularity of genetic material due to non-specific genotoxic exposure $[20,21]$.

Of the complex mixtures to which sewage workers are exposed, are PAHs and other genotoxic chemicals that are metabolized by and induce the expression of cytochrome P450 enzymes (e.g. CYP1A2) [22-24]. The CYP1A2 enzyme is involved in the metabolic activation of a wide range of chemicals and carcinogens like PAHs and aromatic amines $[23,24]$. Its activity has been shown to be increased by smoking, ingestion of charbroiled meat, cruciferous vegetables, PAHs and PCBs exposures [23,25-28]. The catalyzed metabolism by CYP1A2 can generate ROS which might lead to oxidative DNA damage $[22,29,30]$. This damage has been associated with an increased risk of cancer generally ascribed to DNA adducts $[22,31]$. Thus, measurement of CYP1A2 activity in vivo may be an important tool to assess the exposure to chemical carcinogens and cancer risk. PAHs related DNA-adducts measured by ${ }^{32} \mathrm{P}$ - postlabeling technique is frequently described as the biomarker of choice [32-34]. Oxidative DNA damage may be also important in carcinogenesis since the DNA base lesions, such as 8-oxodG, are abundant and highly mutagenic $[35,36]$. However, DNA repair via nucleotide and base excision processes leads to elimination and excretion of 8-oxodG in urine quantitatively without metabolism [37-40]. Urinary excretion of 8oxodG is the most widely used noninvasive urinary 
biomarker of oxidative stress and its measurement in urine has been proposed to assess whole-body oxidative DNA damage [41,42].

The CYP1A2 was shown to be responsible for the 3demethylation of caffeine, which is the initial major step in the biotransformation of caffeine in human's body [43]. Urinary metabolites of dietary caffeine is the most noninvasively-used method in the assessment of CYP1A2 activity [44-46]. Recent studies have demonstrated that the polymorphism of CYP1A2 could be critical in investigating the induction of the enzyme [47]. The $-163 \mathrm{C}>\mathrm{A}$ (allele $\mathrm{CYP} 1 \mathrm{~A} 2 * \mathrm{~F}$ ) polymorphism has been associated with higher enzyme inducibility by smoking [48]. Even if the clinical relevance of this polymorphism remains controversial [47], it is necessary to assess it for a good interpretation of the caffeine metabolism data.

This project is interested in an association of simple, early and non-invasive biomarkers intended to highlight exposure to cocktails of undefined toxic substances having genotoxic properties. We propose to carry out a cross sectional study comparing a particularly exposed category of workers to multiple professional pollutants (Parisians sewage workers) with a non-exposed professional category workers (municipality office workers) by using biomarkers of exposure and early biological effects. The biomarkers dedicated for this study are; the comet and micronucleus tests, which seek the presence of genotoxics in the urine. A second group of biomarkers highlights early effects of these substances; the caffeine test, relevant in the event of exposure to PAHs [49], DNA-adducts in the lymphocytes, a biomarker of early effect indicating the exposure to gentoxics, and urinary 8-oxo-dG, a biomarker of early effect, corresponding to DNA oxidative stress [50]. Our primary objective is to study if the exposed present an increased risk of genotoxic lesions, compared to the nonexposed. The secondary objective is to evaluate the early effects of an exposure to complex genotoxic agents. To achieve these objectives we will; (1) analyze the urine for DNA damage and genotoxicity (using in vitro comet and micronucleus assays and analysis of oxidative stress through $24 \mathrm{~h}$ urinary 8-oxodG), (2) analyze peripheral blood lymphocytes for DNA-adducts by ${ }^{32} \mathrm{P}$-post labelling technique, (3) assess personal exposure to PAHs and VOCs in the workplace environment, and (4) evaluate the PAHs exposure through assessment of CYP1A2 activity by urinary metabolites of dietary caffeine.

The study hypothesis is that exposure of the sewage workers to multiple genotoxics leads to an increase in certain biomarkers of exposure and other biomarkers of early biological effects. The validation of our hypothesis through these biomarkers, would allow the estimation of the total personal exposure to complex mixture of toxic chemicals from different exposure pathways (lungs, skin, and GIT), and different sources (air, diet, lifestyle or occupation), whereas the traditional epidemiological studies don't. Figure 1 presents the theoretical-overview of development from exposure to disease and the study assessment biomarkers.

\section{Methods/Design \\ Study design, population and setting}

This cross sectional study will compare an exposed population (under-ground sewage workers) to a control group (office workers). Both groups are from Paris municipality workers and selected among occupational categories with similar socio-economic status. Participation will be voluntary. Subjects will be current nonsmokers since at least 6 months, aged (20-60) years old, being employed during at least the same period, have no history of chronic or recent illness (diabetes, influenza for example) and are not taking any medication (omeprazole for instance) that could interfere with the study results. As sewage workers are mostly males, the study population will be only of males. The study will be conducted in the framework of regular occupational medical visits. All interviews and primary procedures will be taken place at the offices of occupational medicine in Paris city.

\section{Ethical consideration}

The study protocol was approved by the local ethical committees (CPP, $\mathrm{N}^{\circ}$ 2007-A00685-48). All participants will be given an explanation of the nature of the study, and a signed informed consent will be obtained.

\section{Sampling chronology}

Table 1 shows the weekly sampling chronology of the study participants. Briefly, controls will be frequencymatched for age with sewage workers with a 1 to 1 ratio. After at least three consecutive days of work a $24 \mathrm{~h}$ urinary sample will be collected from all participants (starting at 9:00 a.m). Subjects will receive a urine collecting bottle and written/oral information describing urine collection. After given their urine samples at 9:00 a.m of the next day (Friday), the exposed will undergo medical examination by occupational health physicians. Blood samples will then be taken by nurses. Thereafter, they will receive a cup of decaffeinated coffee added with $110 \mathrm{mg}$ of caffeine. Three hours later, a urine sample will be taken, from which three aliquots (200 $\mu \mathrm{l}$ each) will be collected to assess the urinary caffeine metabolites and the corresponding CYP1A2 activity. During these 3 hours, subjects will fill in two self-administered questionnaires under the supervision of study researchers. A professional one covering socio-demographic factors, non-occupationally exposures (especially PAHs-related: commuting means, area of residence and indoor sources), medical history, lifestyle (smoking history including passive smoking 


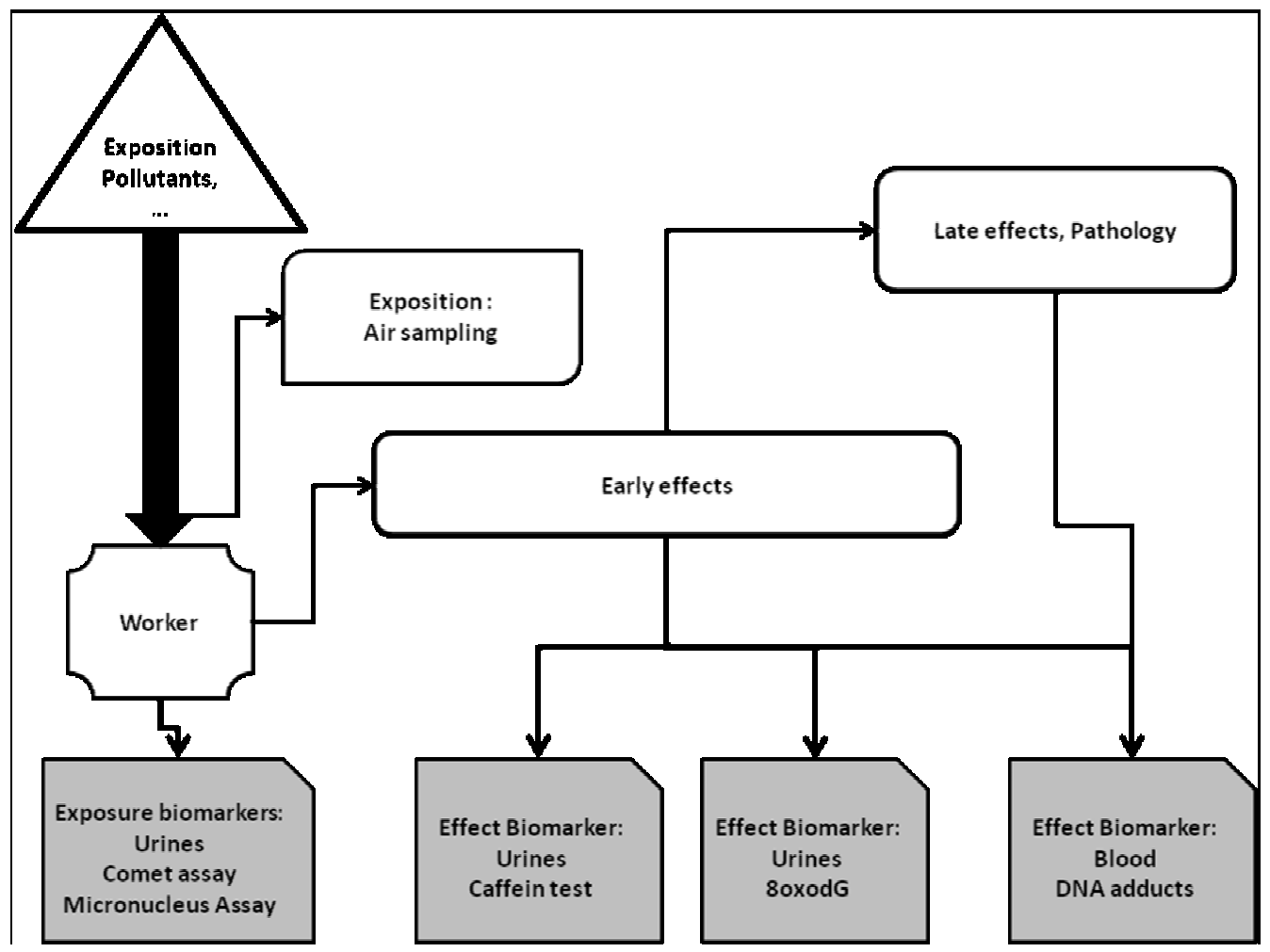

Figure I

Schematic diagram of progression from exposure to disease and the study assessment tools and biomarkers.

exposure, alcohol and medications) and other confounders. The other is an alimentary questionnaire collecting detailed-data on diet habits [51]. For the control group, the sequence will be the same but start at 13:30 p.m.

Blood and urine samples will be processed on the same day as described further. For the $48 \mathrm{~h}$ before and during the 3 hours of the caffeine test, subjects will be asked to avoid diets or cooking procedures known to increase CYP1A2 activity or elicit urinary mutagenicity (e.g., cruci- ferous vegetables; charcoal-broiled or grilled meat) or inhibit CYP1A2 (e.g., grapefruit). They will also be asked to refrain from consuming alcoholic drinks and beverages containing methylxanthines and to avoid massive physical activity as it could increase DNA damage [52,53]. In table 1 we present the morning sampling chronology for the exposed participants.

Table I: Morning sampling chronology of study participants.

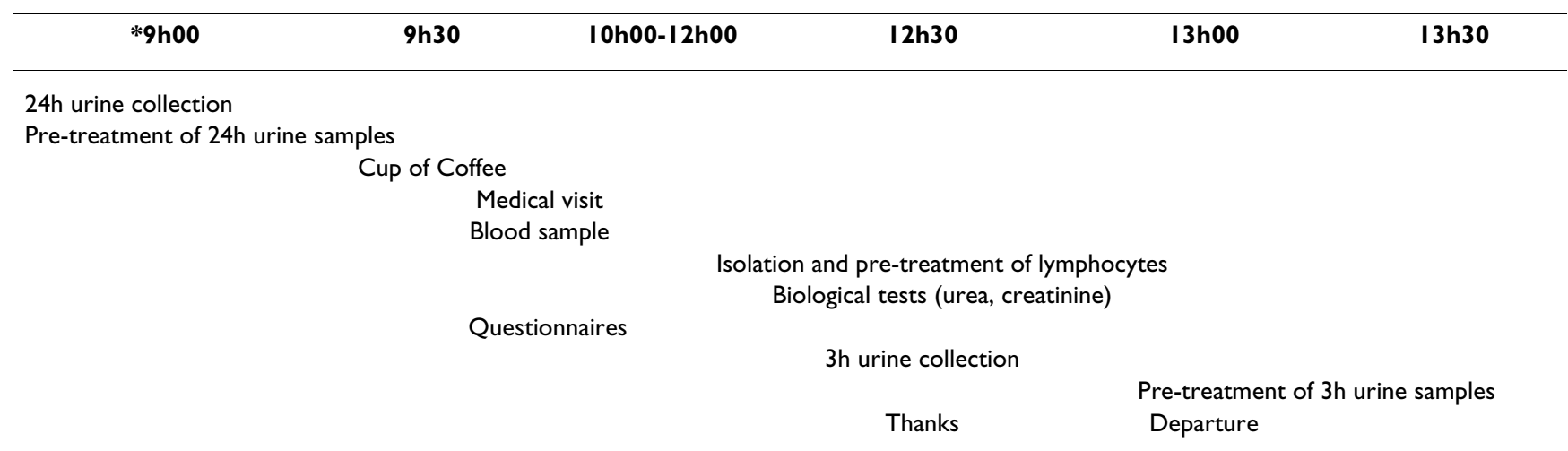

*Friday of each week. In each study week, 16 participants will be sampled (8 exposed in the morning and 8 non-exposed in the corresponding afternoon). 


\section{Occupational atmospheric sampling}

During the first part of the week, before coming to the medical examination, the air of the working places will be collected to be assessed for their COV or HAP content.

\section{Sample size}

Sample size was calculated for a type ${ }^{2}$ error $(\alpha)$ of $5 \%$ and power expectation of $80 \%$. In a non-exposed population, urines are not mutagenic in theory, and both genotoxicity tests should be negative. Thus, if the expected prevalence in the control is $1 \%$, a number of 75 subjects in each group are sufficient to highlight a prevalence of the anomalies of $17 \%$ in the exposed. The number of subjects necessary for DNA-adducts study is similar. For urinary 8oxo-dG, the expected value in reference (control) population is nearly $10.78 \pm 6.6$ (Mean \pm SD) nmole/24h, [54]. Thus 75 subjects in each group are sufficient to detect $18 \%$ modification of this value. For CYP1A2 activity, the urinary "molar concentration ratio of 1, 7-dimethylurate plus paraxanthine over caffeine" measured in a reference population is $5.6 \pm 1.5$ (Mean \pm SD) [55], so 75 subjects in each group allow to detect a modification of $13 \%$ of this ratio.

As describe above, 16 subjects ( 8 exposed and 8 nonexposed) will be sampled Each week,. This will result in 10 weeks of sampling procedures to complete data collection according to study sample size of 75 subjects in each group. Each corresponding afternoon, 8 non-exposed participants will follow a similar sampling procedure.

The Parisians sewage workers are nearly 400 individuals, recruitment will be comfortable, even after exclusion of smokers (approximately 45\%) [7].

\section{Experimental protocol and technique Isolation of lymphocytes}

This will be carried out using Ficoll gradient centrifugation method of Bøyum [56] with few modifications according to the study conditions. Briefly, $25 \mathrm{ml}$ of freshly obtained venous blood will be collected on anticoagulant (EDTA) and diluted with an equal volume of standard balanced salt solution and layered carefully over FicollPaque Plus density gradient medium, without intermixing, in a centrifuge tube. After centrifuging at room temperature (400 $\mathrm{g}$ for 30-40 $\mathrm{min}$ ), drawing of the upper layer by a clean Pasteur pipette will be done leaving the lymphocytes layer undisturbed at the interface. The upper layer which contains the plasma will be saved for later usual clinical chemistry tests. Using a clean Pasteur pipette the lymphocytes layer will be harvested from the interface and transferred to a clean centrifuge tube. Then it will be centrifuged twice $\left(60-100 \mathrm{~g}\right.$ for $10 \mathrm{~min}$ at $18-20^{\circ} \mathrm{C}$ ) in a balanced salt solution to wash the lymphocytes and remove any remnants of platelets. The lymphocytes will be suspended with 10\% DMSO, coded, and frozen at $80^{\circ} \mathrm{C}$ until extraction of DNA.

\section{Extraction of DNA}

Frozen lymphocytes suspensions will be thawed in a $37^{\circ} \mathrm{C}$ water bath with gentle agitation. DNA extraction will be carried out using a standard phenol-chloroform method including treatment with RNAses as described elsewhere [57]. DNA purity will be checked by determination of UV spectra between 228 and $300 \mathrm{~nm}$ (associated with ratio values: $1.8<\mathrm{A} 260 / \mathrm{A} 280<1.95$ and $\mathrm{A} 260 /$ A230>2.3) and the DNA concentration will be deduced from the A260, as described [58]. DNA solutions will be divided into three portions and frozen at $-80^{\circ} \mathrm{Cin}$ glass vials.

\section{Polymerase chain reaction "PCR" analysis of the CYPIA2}

The polymorphism of CYP1A2 will be assessed by realtime polymerase chain reaction and melting curve analysis, as described by Casley and LeBlanc-Westwood [59]. Reactions will be carried out in $20 \mu \mathrm{L}$ volumes containing $3.5 \mathrm{mM} \mathrm{MgCl}_{2}$ and $50 \mathrm{pg}$ genomic DNA, using Fast Start DNA master mix for hybridization probes from Roche Diagnostics. All conditions will be adapted from Casley and LeBlanc-Westwood [59].

\section{Analysis of DNA-adducts}

DNA-adducts will be analyzed by ${ }^{32} \mathrm{P}$-postlabelling assay as described $[60,61]$, using Nuclease P1 for enrichment, with modifications from le Goff [57]. Briefly, $5 \mu \mathrm{g}$ of DNA will be digested, then $\mu \mathrm{Ci} \gamma$-32P-ATP. Separation will be achieved on thin layer chromatography. Autoradiograms will be obtained after exposure of Kodak Biomax film to the TLC-plates. Each sample will be analyzed two times and in at least two different experiments. The detection limit will be fixed at $0.02 \times 10^{-10}$, i.e. half of the lowest quantifiable Relative Adduct Level (RAL) value. For qualitative analysis, the mean number of adducts per individual will be calculated.

\section{Pre-treatment of urine samples}

The volume of the $24 \mathrm{~h}$ urine collected in sterile plastic urine collection bottles will be measured immediately and expressed per subject and body weight. Then, three 10 $\mathrm{ml}$ aliquots will be coded and frozen at $-20^{\circ} \mathrm{C}$ for 8 oxodG analysis. Another up to $100 \mathrm{ml}$ aliquots will be coded and frozen at $-20^{\circ} \mathrm{C}$ for organic extraction and genotoxicity tests. Both samples will be transferred to the laboratory of analysis (within the same day). The concentration of 8 -oxodG in urine stored at $-20^{\circ} \mathrm{C}$ was shown to be constant for at least 3 years [62].

\section{Measurement of 8-oxodG concentration in 24h urine}

This will be done as described [63]. Briefly, frozen urine samples will be thawed at $37^{\circ} \mathrm{C}$ for $25 \mathrm{~min}$, mixed and 
cooled to room temperature. HPLC separation will be performed on a C18 HPLC column $(150 \times 2 \mathrm{~mm}, 5 \mu)$ protected by a C18 guard column $(10 \times 2 \mathrm{~mm}, 5 \mu)$. The mobile phase for urine samples will be $10 \mathrm{mM}$ ammonium formate, adjusted to $\mathrm{pH} 3.75$ with formic acid and $2 \%$ acetonitrile. Electrospray will be performed in the positive ion mode. A stable isotopically marked internal standard of 8-oxodG will be used ( $\left[{ }^{15} \mathrm{~N}_{5}\right]$ 8-oxo-dG) (for details, see reference 63).

\section{Urine organic extracts}

This will be carried on Sep-Pak C18 cartridges (Waters Associates, Inc) adsorption chromatography as described [64] with some modifications. Briefly, frozen urine samples will be thawed at room temperature and filtered through Whatman filter paper No. 1. Then it will be adjusted to $\mathrm{pH} 7$ using $0.1 \mathrm{M} \mathrm{NaOH}$. The cartridge will firstly be washed 3 times with $3 \mathrm{ml}$ of absolute methanol and $3 \mathrm{ml}$ of ultra-pure water successively before preparation of the columns. Then, the cartridge will be loaded with urine using a glass powder funnel on the column to facilitate the loading process. All operations will be at room temperature. The column will then be washed 3 times with $10 \mathrm{ml}$ distilled water in order to eliminate the residual urine and histidine. The adsorbed components will then be eluted with methanol $(5 \mathrm{ml} / 100 \mathrm{ml}$ urine) into glass test tube. The eluate will be dried at $40^{\circ} \mathrm{C}$ under a nitrogen stream until complete dryness. Then, the residue will be dissolved in DMSO $(0.4 \mathrm{ml} / 100 \mathrm{ml}$ urine $)$ and stored at $-20^{\circ} \mathrm{C}$ until analysis of genotoxicity tests.

\section{Cell culture}

For the two tests (comet and micronucleus) two cell lines will be used. HeLa S3 cellular line cells will be used (ECACC, catalog number 87110901, adherent cells of human cervical carcinoma). Hep G2 is a perpetual adherent cell line which was derived from the liver tissue of a 15 year old caucasian male with a well differentiated hepatocellular carcinoma (ATCC, catalog number HB-8065).

\section{Comet assay "Single Cell Gel Electrophoresis" (SCGE)}

The urine extracts kept at $-20^{\circ} \mathrm{C}$ will be thawed and warmed to room temperature shortly before the assay. Comet assay will be performed basically according to Sing et al. 1988 [65], with modifications according to Muller et al. 2000 [66]. Briefly, the cells will be incubated with the organic extract of urine $(200 \mu \mathrm{l})$ during $24 \mathrm{~h}$ (typical division duration of these cells). Viability of cells will be determined by trypan blue test. Microscopic slides will be precoated with $100 \mu \mathrm{l}$ of agarose (1\%). The slides will be gently immersed in ice-cold freshly lysis solution and will be covered with fresh electrophoresis buffer for $20 \mathrm{~min}$ and placed in a horizontal electrophoresis unit tank filled with new fresh electrophoresis buffer. After electrophoresis, they will be washed with a freshly made neutralizing buffer and stained with $50 \mu$ l ethidium bromide solution. They will then be examined for analysis of DNA migration under a fluorescence microscope (Olympus BX-40, Olympus, Japan) using a computerized image analysis system (Komet 5, Kinetic Imaging). Two slides will be analyzed for each sample with fifty cells scored in each slide. Olive tail moment will be used for analysis of results [67].

\section{Micronucleus assay}

It will be performed according to the standard protocol of the International Workshops on Genotoxicity Test Procedures $[17,68,69]$. Briefly, after the initial screening; wellprepared slides will be scored using a high power magnification (400-1000 folds) with both bright field and phase-contrast microscope. Frequency of micronucleated cells will be evaluated by the number of cells containing one or more micronuclei (but less than 5). The induction factor will be calculated by dividing treated values by the control ones. Chi-square will be used for the comparisons and when $P$ value is $<0.05$ the concentration will be considered positive.

\section{Assessment of CYPIA2 activity by urinary caffeine metabolites}

Subjects will be instructed to empty their bladder. Then they will receive a cup of decaffeinated coffee added with $110 \mathrm{mg}$ caffeine. Three hours later, a urine sample will be collected and transferred to tube with $1 \mathrm{ml} \mathrm{HCl}$, pH 3.5. Samples will be coded and frozen at $-20^{\circ} \mathrm{C}$ and then transferred to the laboratory of analysis (within the same day), where it will be stored at $-20^{\circ} \mathrm{C}$ until HPLC analysis. Caffeine and its metabolites will be extracted as described [55]. Briefly, the concentrated residue will be dissolved in $800 \mu \mathrm{l}$ of $0.05 \%$ acetic acid and filtered through a 0.45 $\mu \mathrm{m}$ filter. Here, $100 \mu \mathrm{l}$ of the filtrate will be injected into HPLC column. Caffeine and its metabolites will be analyzed using an HPLC system as described elsewhere [70]. The metabolites will be identified and quantified by UV detector with a computerized photodiode array detector as compared with definite standards [1,7-dimethylurate (17 U), 1,7-dimethylxantine (17X), and 1,3,7-trimethylxanthine (137X)]. To assess CYP1A2 activity, urinary molar concentration ratio index [17U $+17 \mathrm{X} / 137 \mathrm{X}]$ will be used as it reflects caffeine 3-demethylation activity in this phenotyping procedure $[71,72]$.

\section{Occupational air sampling}

The targeted indicators will be VOCs and PAHs. They have been selected because they are present in the confined environments of the sewers while also emitted by automobile traffic, hence present in ambient and indoor atmospheres, and because they are of health significance.

Since the sewage system is deprived of electricity, air sampling will be carried out using battery-powered devices or 
passive samplers. The sampling procedure will strive at evaluating exposure near the breathing zone. However, not to disturb the sewage workers, measurements will be done by a companion worker (or a study personnel) who will accompany each studied team and carry the sampling equipment in a back bag. For the reference population (office workers) the same type of sampling materials will be placed in a bag located in the working area, for example on a desk.

\section{Measurement of Volatile Organic Compounds (VOCs)}

Collection of VOCs will be carried out on thermal desorption sorbent tubes exposed during the sewage workers worktime from Monday to Thursday and the sampler is recapped after every exposure. Analysis will be carried out by coupling gas chromatography and mass spectrometry. As work in sewage system takes place in a wet environment, a sorbent tube not very sensitive to moisture will be chosen. The list of the selected indicators will be at least the substances measured inside residences within the framework of the national inventory carried out by the Observatory of Indoor Air Quality (OIAQ) in more than 560 French residences. These data were published in November 2006 [73] and can be used as reference values. It is probable that most of compounds found in the residences are also present in the air of the offices. The basic list is as follows:

\section{- Alkanes: decane, undecane}

- Monocyclic aromatic hydrocarbons: benzene, toluene, meta and para-xylenes, orthoxylene, 1, 2, 4-trimethylbenzene, styrene

- Chlorinated hydrocarbons: trichloroethylene, tetrachloroethylene, 1-4-dichlorobenzene.

The tubes used for sampling will be analyzed at the Paris city hygiene laboratory on a chain including a thermal desorption module on line with a chromatograph in gas phase equipped with a capillary column and coupled to a mass spectrometer (Quadripole). Quantitative analysis will be carried out on the basis of ion extracts and a range of calibration prepared by doping a lot of sorbent tubes with various quantities of a mixture of the selected VOCs. The first samples ( 2 to 3 ) will be devoted to the qualitative analysis (screening) of the chromatographic profiles with the aim to adjust the list of targeted compounds.

\section{Measurement of Polycyclic Aromatic Hydrocarbons}

They will be collected with personal air samplers allowing the simultaneously trapping of the volatile and the particulate phases (in case of heavy loss of charge due to high charged XAD2 resin, it will be necessary to carry out two distinct samples, one collecting only gaseous PAHs, the second one for particulate PAHs). The head of the samplers will consist of a cassette containing a filter, to collect particles coupled to a marketed tube filled with XAD2 resin or polyurethane foam. Air will be drawn using a constant flow sampling pump at a calibrated flow-rate of $2 \mathrm{~L} /$ $\min$.

Duration of sampling will be at least equal to the daily worktime. However, four consecutive days of cumulative sampling may be necessary because concentrations are expected to be low. In this case, filter will be preserved in an aluminum sheet to avoid photochemical transformations. A first series of measurements will allow determination of the minimal duration of exposure for an acceptable quantification limit.

Thirteen PAHs will be measured: phenanthrene, anthracene, fluoranthene, pyrene, benzo(a)anthracene, chrysene, benzo(j)fluoranthene, benzo(b)fluoranthene, benzo(k)fluoranthene, benzo(a)pyrene, dibenzo(a,h) anthracene, benzo(g,h,i) perylene, indeno-pyrene. PAHs will be extracted at the laboratory by a solvent in a pressurized cell, so the extracts will be concentrated in an automatic evaporator. They will be analyzed by high HPLC associated with fluorimetric detection. A binary elution gradient consisting of water and acetonitrile will be used to separate the different PAHs. Several couples of wavelengths of excitation and emission will be selected to optimize the sensitivity of the response of the compounds and to limit the chromatographic interferences. The quantitative analysis will be carried out according to the response of standard solutions that are prepared from a marketed mixture of the selected PAHs.

\section{Statistical analysis}

For each parameter, data will be compared between the exposed and non-exposed groups. Data will be tested for homogeneity of variance and normality after variable transformation if appropriate. Two-tailed Student's t-test will be used for group and/or sample comparisons relative to DNA-adducts level. Fisher's exact test will also be used for comparison of DNA-adducts pattern distributions between groups. Linear regression analysis will be used for quantitative variables, adjusting for parameters that reflect exposures in the questionnaires. For other parameters, ANOVA will be performed. Correlation analysis of DNAadducts levels and urine genotoxicity with qualitative parameters will be evaluated by Spearman tests. Potential confounding factors, like age, socioeconomic or passive smoking will be studied, mainly by evaluating their distribution in both groups and by looking for possible association with DNA-adducts levels, urine genotoxicity or caffeine metabolism tests. The influence of confounding factors will be determined by multiple logistic regression after a check of normality (Kolmogorov Smirnov's test). 
The analysis will be processed by the statistical software SAS (SAS Inc., Version 8.02).

\section{Discussion}

This study aims to investigate the carcinogenic risk associated with occupational exposure of sewage workers to complex chemical mixtures. While the comet assay can detect DNA reparable lesions or alkali-labile sites, micronucleus can detect fixed mutations that persist at least one mitotic cycle [74]. Positive results in the comet don't necessarily correspond to positive results in the micronucleus, especially when genotoxic exposure is small. Thus, the combination of both assays might be more accurate and reasonable. Urinary excretion of 8-oxodG is a repair product of oxidative DNA damage and under the usual steady conditions it reflects the general average risk of a promutagenic oxidative stress in DNA of all tissues and organs [75]. Further, DNA-adducts in peripheral lymphocytes is considered as a good biomarker when studying the early effect of genotoxic exposures in humans $[76,77]$.

This study is limited by its cross sectional design where systematic differences between exposed and non-exposed could cause under or overestimation of the risk, as exposed subjects may be more motivated to participate than non-exposed. However, genotoxicity tests (urine and lymphocytes) are not likely to be affected by the subjects' interest to the study. Moreover, choosing office workers as a control group may alleviate sources of strong bias such as "healthy worker effect" and social class differences, as both groups belong to the same socioeconomic class. Further, urine genotoxicity is a short-term measure that reflects exposure 24 to $72 \mathrm{~h}$ before collection [78] and our blood samples will be taken at rest. Airborne assessment will assess exposure by inhalation only, thus possibly misclassifying exposure both quantitatively and qualitatively. Using biomarkers of exposure and of early effects aims to overcome this shortcoming in view to assess the risk. Some difficulties might stem fromthe tiny amounts of promutagens in urine and the presence of urinary histidine, that leads to false positive results. Filtration and concentration of urine might help to solve these problems [64]. Finally, day to day variability in laboratory procedures will be calculated and estimated by analysis.

To summarize, sewage workers are exposed to multiple chemicals from multiple pathways resulting in a complicated matrix of exposure to chemicals and concentrations. In this complex chemical exposure setting, this study combines biological sampling, both in blood and urine, to assess biomarkers of exposure and of early biological effects. These biological indicators will be scaled with results of workplace environment air sampling that will be conducted in parallel. Such biomarkers of exposure and of early biological effects may help overcome the severe limitations of environmental exposure assessment in very complex occupational or environmental settings. If shown discriminating in the framework of this study population, these non-specific biomarkers might be used to assess the genotoxic risk in other populations also experiencing complex exposures.

\section{Abbreviations}

CI-Confidence interval, CYP1A2-Cytochrome P1A2, DNA-Deoxyribo-nucleic Acid, EDTA-Ethylene-diaminetetra-acetic acid, HCl-Hydrochloric acid, HPLC-High performance liquid chromatography, MgCL2-Magnesium chloride, $\mathrm{MN}-\mathrm{Micronucleus,} \mathrm{PAHs-Polycyclic} \mathrm{aro-}$ matic hydrocarbons, SMR-Standardized mortality rate, VOCs-Volatile organic compounds, 8-oxodG-8-Oxo-7, 8-Dihydro-2'-deoxy-Guanosine

\section{Competing interests}

The author(s) declare that they have no competing interests.

\section{Authors' contributions}

HA drafted the manuscript. LF, DZN and CP participated in the design and coordination of the study protocol and helped to draft the manuscript. Other authors reviewed the manuscript, provided further contributions and suggestions. All authors read and approved the final manuscript.

\section{Acknowledgements}

HA is supported by the French Foreign Ministry and The faculty of Medicine of Nancy, The project is granted by The French National Cancer Institut and the Région Lorraine. The authors thank Yvon Le Moullec and MarieAude Kerautre for their careful reading of the paper.

\section{References}

I. Bridges O: Double trouble: health risks of accidental sewage release. Chemosphere 2003, 52:I373-9.

2. Aguayo S, Munoz MJ, de la Torre A, Roset J, de la Pena E, Carballo M: Identification of organic compounds and ecotoxicological assessment of sewage treatment plants (STP) effluents. $\mathrm{Sci}$ Total Environ 2004, 328:69-8I.

3. Blanchard M, Teil MJ, Ollivon D, Legenti L, Chevreuil M: Polycyclic aromatic hydrocarbons and polychlorobiphenyls in wastewaters and sewage sludges from the Paris area (France). Environ Res 2004, 95: 184-97.

4. Krishnamurthi K, Devi F, Chakrabarti T: Genotoxic effects of PAH containing sludge extracts in Chinese hamster ovary cell cultures. Biomed Environ Sci 2003, 16:68-82.

5. Sorensen M, Skov H, Autrup H, Hertel O, Loft S: Urban benzene exposure and oxidative DNA damage: influence of genetic polymorphisms in metabolism genes. Sci Total Environ 2003, 309:69-80.

6. Lan Q, Mumford JL, Shen M, Demarini DM, Bonner MR, He X, Yeager M, Welch R, Chanock S, Tian L, Chapman RS, Zheng T, Keohavong P, Caporaso $N$, Rothman $N$ : Oxidative damage-related genes AKRIC3 and OGGI modulate risks for lung cancer due to exposure to PAH-rich coal combustion emissions. Carcinogenesis 2004, 25:2177-8I.

7. Wild P, Ambroise D, Benbrik E, Tiberguent A, Massin N: Mortality among Paris sewage workers. Occup Environ Med 2006, 63:168-72. 
8. Lafleur J, Vena JE: Retrospective cohort mortality study of cancer among sewage plant workers. Am J Ind Med I99I, 19:75-86.

9. Friis L, Mikoczy Z, Hagmar L, Edling C: Cancer incidence in a cohort of Swedish sewage workers: extended follow up. Occup Environ Med 1999, 56:672-3.

10. Hansen ES, Hilden J, Klausen H, Rosdahl N: Wastewater exposure and health: a comparative study of two occupational groups. Occup Environ Med 2003, 60:595-8.

II. Olin RG, Ahlbom A, Lindberg-Navier I, Norell SE, Spannare B: Occupational factors associated with astrocytomas: a case-control study. Am J Ind Med 1987, I I:6I5-25.

12. Scarlett-Kranz JM, Babish JG, Strickland D, Goodrich RM, Lisk DJ: Urinary mutagens in municipal sewage workers and water treatment workers. Am J Epidemiol 1986, I 24:884-93.

13. Ma XF, Babish JG, Scarlett JM, Gutenmann WH, Lisk DJ: Mutagens in urine sampled repetitively from municipal refuse incinerator workers and water treatment workers. I Toxicol Environ Health 1992, 37:483-94.

14. Lebailly P, Devaux A, Pottier D, De Meo M, Andre V, Baldi I, Severin F, Bernaud J, Durand B, Henry-Amar M, Gauduchon P: Urine mutagenicity and lymphocyte DNA damage in fruit growers occupationally exposed to the fungicide captan. Occup Environ Med 2003, 60:910-7.

15. Hansen AM, Wallin H, Binderup ML, Dybdahl M, Autrup H, Loft S, Knudsen LE: Urinary I-hydroxypyrene and mutagenicity in bus drivers and mail carriers exposed to urban air pollution in Denmark. Mutat Res 2004, 557:7-17.

16. Simioli P, Lupi S, Gregorio P, Siwinska E, Mielzynska D, Clonfero E, Pavanello S: Non-smoking coke oven workers show an occupational PAH exposure-related increase in urinary mutagens. Mutat Res 2004, 562:103-10.

17. Kirsch-Volders M, Sofuni T, Aardema M, Albertini S, Eastmond D, Fenech M, Ishidate M Jr, Kirchner S, Lorge E, Morita T, Norppa $H$ Surralles J, Vanhauwaert A, Wakata A: Report from the in vitro micronucleus assay working group. Mutat Res 2003, 540:153-63.

18. Marczynski B, Raulf-Heimsoth M, Preuss R, Kappler M, Schott K Pesch B, Zoubek G, Hahn JU, Mensing T, Angerer J, Kafferlein HU, Bruning T: Assessment of DNA damage in WBCs of workers occupationally exposed to fumes and aerosols of bitumen Cancer Epidemiol Biomarkers Prev 2006, 15:645-5I.

19. Abou Chakra OR, Joyeux M, Nerriere E, Strub MP, Zmirou-Navier D: Genotoxicity of organic extracts of urban airborne particulate matter: an assessment within a personal exposure study. Chemosphere 2007, 66: I375-8I.

20. Bonassi S, Ugolini D, Kirsch-Volders M, Stromberg U, Vermeulen R, Tucker JD: Human population studies with cytogenetic biomarkers: review of the literature and future prospectives. Environ Mol Mutagen 2005, 45:258-70.

21. Lorge E, Thybaud V, Aardema MJ, Oliver J, Wakata A, Lorenzon G, Marzin D: SFTG international collaborative study on in vitro micronucleus test I. General conditions and overall conclusions of the study. Mutat Res 2006, 607:13-36.

22. Szeliga J, Dipple A: DNA adduct formation by polycyclic aromatic hydrocarbon dihydrodiol epoxides. Chem Res Toxicol 1998, I I:I-I I.

23. Landi MT, Sinha R, Lang NP, Kadlubar FF: Human cytochrome P450IA2. IARC Sci Publ 1999, I 48: 173-95.

24. Rundle A, Tang D, Zhou J, Cho S, Perera F: The association between glutathione $S$ transferase $M I$ genotype and polycyclic aromatic hydrocarbon-DNA adducts in breast tissue. Cancer Epidemiol Biomarkers Prev 2000, 9:1079-85.

25. Sinha R, Rothman N, Brown ED, Mark SD, Hoover RN, Caporaso NE, Levander OA, Knize MG, Lang NP, Kadlubar FF: Pan-fried meat containing high levels of heterocyclic aromatic amines but low levels of polycyclic aromatic hydrocarbons induces cytochrome P450IA2 activity in humans. Cancer Res 1994, 54:6154-9.

26. Safe $\mathrm{SH}$ : Modulation of gene expression and endocrine response pathways by $2,3,7,8$ tetrachlorodibenzo-p-dioxin and related compounds. Pharmacol Ther 1995, 67:247-81.

27. Kall MA, Clausen J: Dietary effect on mixed function P450 IA2 activity assayed by estimation of caffeine metabolism in man. Hum Exp Toxicol 1995, 14:801-7.

28. Li W, Harper PA, Tang BK, Okey AB: Regulation of cytochrome P450 enzymes by aryl hydrocarbon receptor in human cells:
CYPIA2 expression in the LSI80 colon carcinoma cell line after treatment with 2,3,7,8-tetrachlorodibenzo-p-dioxin or 3 methylcholanthrene. Biochem Pharmacol 1998, 56:599-6I2.

29. Loft S, Deng XS, Tuo J, Wellejus A, Sorensen M, Poulsen HE: Experimental study of oxidative DNA damage. Free Radic Res 1998, 29:525-39.

30. Bonvallot V, Baeza-Squiban A, Baulig A, Brulant S, Boland S, Muzeau F, Barouki R, Marano F: Organic compounds from diesel exhaust particles elicit a proinflammatory response in human airway epithelial cells and induce cytochrome p450 IAI expression. Am J Respir Cell Mol Biol 200I, 25:5 I5-2I.

31. Cheng YW, Chen CY, Lin P, Huang KH, Lin TS, Wu MH, Lee H: DNA adduct level in lung tissue may act as a risk biomarker of lung cancer. Eur J Cancer 2000, 36:138I-8.

32. Sram RJ, Binkova B: Molecular epidemiology studies on occupational and environmental exposure to mutagens and carcinogens, 1997-1999. Environ Health Perspect 2000, I08(Suppl I): $57-70$.

33. Castano-Vinyals G, D'Errico A, Malats N, Kogevinas M: Biomarkers of exposure to polycyclic aromatic hydrocarbons from environmental air pollution. Occup Environ Med 2004, 61 : I2.

34. Peluso M, Munnia A, Hoek G, Krzyzanowski M, Veglia F, Airoldi L, Autrup H, Dunning A, Garte S, Hainaut P, Malaveille C, Gormally E, Matullo G, Overvad K, Raaschou-Nielsen O, Clavel-Chapelon F, Linseisen J, Boeing H, Trichopoulou A, Trichopoulos D, Kaladidi A, Palli D, Krogh V, Tumino R, Panico S, Bueno-De-Mesquita HB, Peeters PH, Kumle M, Gonzalez CA, Martinez C, Dorronsoro M, Barricarte A, Navarro C, Quiros JR, Berglund G, Janzon L, Jarvholm B, Day NE, Key T], Saracci R, Kaaks R, Riboli E, Vineis P: DNA adducts and lung cancer risk: a prospective study. Cancer Res 2005, 65:8042-8.

35. Loft S, Poulsen HE: Cancer risk and oxidative DNA damage in man. J Mol Med 1996, 74:297-3I2.

36. Kasai H: Analysis of a form of oxidative DNA damage, 8hydroxy-2' deoxyguanosine, as a marker of cellular oxidative stress during carcinogenesis. Mutat Res 1997, 387: 147-63.

37. Loft S, Poulsen HE: Antioxidant intervention studies related to DNA damage, DNA repair and gene expression. Free Radic Res 2000, 33(Suppl):67-83.

38. Nishimura S: Involvement of mammalian OGGI(MMH) in excision of the 8 hydroxyguanine residue in DNA. Free Radic Biol Med 2002, 32:8I3-2I.

39. Bjelland S, Seeberg E: Mutagenicity, toxicity and repair of DNA base damage induced by oxidation. Mutat Res 2003, 53 I:37-80.

40. Moller P, Vogel U, Pedersen A, Dragsted LO, Sandstrom B, Loft S: No effect of $\mathbf{6 0 0}$ grams fruit and vegetables per day on oxidative DNA damage and repair in healthy nonsmokers. Cancer Epidemiol Biomarkers Prev 2003, 12:1016-22.

4I. Loft S, Poulsen HE: Markers of oxidative damage to DNA: antioxidants and molecular damage. Methods Enzymol 1999, 300:166-84

42. Olinski R, Rozalski R, Gackowski D, Foksinski M, Siomek A, Cooke MS: Urinary measurement of 8-OxodG, 8-OxoGua, and 5HMUra: a noninvasive assessment of oxidative damage to DNA. Antioxid Redox Signal 2006, 8: I0II-9.

43. Berthou F, Guillois B, Riche C, Dreano Y, Jacqz-Aigrain E, Beaune PH: Interspecies variations in caffeine metabolism related to cytochrome P450 IA enzymes. Xenobiotica 1992, 22:67I-80.

44. Nakajima M, Yokoi T, Mizutani M, Kinoshita M, Funayama M, Kamataki T: Genetic polymorphism in the 5 '-flanking region of human CYPIA2 gene: effect on the CYPIA2 inducibility in humans. J Biochem (Tokyo) 1999, I 25:803-8.

45. Seow A, Zhao B, Lee EJ, Poh WT, Teh M, Eng P, Wang YT, Tan WC, Lee HP: Cytochrome P450IA2 (CYPIA2) activity and lung cancer risk: a preliminary study among Chinese women in Singapore. Carcinogenesis 200I, 22:673-7.

46. Fanlo A, Sinues B, Mayayo E, Bernal L, Soriano A, Martinez-Jarreta B, Martinez-Ballarin E: Urinary mutagenicity, CYPIA2 and NAT2 activity in textile industry workers. J Occup Health 2004, 46:440-7.

47. Ghotbi R, Christensen M, Roh HK, Ingelman-Sundberg M, Aklillu E, Bertilsson L: Comparisons of CYPIA2 genetic polymorphisms, enzyme activity and the genotype-phenotype relationship in Swedes and Koreans. Eur ] Clin Pharmacol 2007, 63:537-46.

48. Sachse C, Brockmoller J, Bauer S, Roots I: Functional significance of a C->A polymorphism in intron I of the cytochrome $\mathbf{P 4 5 0}$ 
CYPIA2 gene tested with caffeine. Br J Clin Pharmacol 1999, 47:445-449.

49. Faber MS, Jetter A, Fuhr U: Assessment of CYPIA2 activity in clinical practice: why, how, and when? Basic Clin Pharmacol Toxicol 2005, 97: 125-34.

50. Wu LL, Chiou CC, Chang PY, Wu JT: Urinary 8-OHdG: a marker of oxidative stress to DNA and a risk factor for cancer, atherosclerosis and diabetics. Clin Chim Acta 2004, 339:1-9.

5I. Preziosi P, Galan P, Aissa M, Hercberg S, Boccalon H: Prevalence of venous insufficiency in French adults of the SUVIMAX cohort. Supplementation en Vitamines et Mineraux Antioxydants. Int Angiol 1999, I 8: I7I-5.

52. Poulsen HE, Weimann A, Loft S: Methods to detect DNA damage by free radicals: relation to exercise. Proc Nutr Soc 1999, 58:1007-I4.

53. Tsai K, Hsu TG, Hsu KM, Cheng H, Liu TY, Hsu CF, Kong CW: Oxidative DNA damage in human peripheral leukocytes induced by massive aerobic exercise. Free Radic Biol Med 200I, 3I:1465-72.

54. Loft S, Poulsen HE, Vistisen K, Knudsen LE: Increased urinary excretion of 8-oxo-2'-deoxyguanosine, a biomarker of oxidative DNA damage, in urban bus drivers. Mutat Res 1999 44I:II-9.

55. Ryu SD, Chung WG: Induction of the procarcinogen-activating CYPIA2 by a herbal dietary supplement in rats and humans. Food Chem Toxicol 2003, 41:86I-6.

56. Boyum A: Isolation of mononuclear cells and granulocytes from human blood. Isolation of monuclear cells by one centrifugation and of granulocytes by combining centrifugation and sedimentation at I g. Scand J Clin Lab Invest 1968:77-89.

57. Le Goff J, Andre V, Lebailly P, Pottier D, Perin F, Perin O, Gauduchon $P$ : Seasonal variations of DNA-adduct patterns in open field farmers handling pesticides. Mutat Res 2005, 587:90-102.

58. Godschalk RW, Maas LM, Kleinjans JC, Van Schooten FJ: Influences of DNA isolation and RNA contamination on carcinogenDNA adduct analysis by $32 \mathrm{P}$ postlabeling. Environ Mol Mutagen 1998, 32:344-50.

59. Casley WL, LeBlanc-Westwood CA: Assay for the simultaneous detection of the *IC and *IF alleles of the CYPIA2 gene by real-time polymerase chain reaction and melting curve analysis. Psychiatr Genet 2006, 16:8I-3.

60. Randerath K, Reddy MV, Gupta RC: 32P-labeling test for DNA damage. Proc Natl Acad Sci USA 198I, 78:6I26-9.

61. Reddy MV, Randerath K: Nuclease PI-mediated enhancement of sensitivity of 32P postlabeling test for structurally diverse DNA adducts. Carcinogenesis 1986, 7:|543-5I.

62. Loft S, Velthuis-te Wierik EJ, van den Berg H, Poulsen HE: Energy restriction and oxidative DNA damage in humans. Cancer Epidemiol Biomarkers Prev 1995, 4:515-9.

63. Weimann A, Belling D, Poulsen HE: Measurement of 8-oxo-2'deoxyguanosine and 8 oxo-2'-deoxyadenosine in DNA and human urine by high performance liquid chromatographyelectrospray tandem mass spectrometry. Free Radic Biol Med 200I, 30:757-64.

64. Kuenemann-Migeot C, Callais F, Momas I, Festy B: Urinary promutagens of smokers: comparison of concentration methods and relation to cigarette consumption. Mutat Res 1996, 368: $|4|-7$.

65. Singh NP, McCoy MT, Tice RR, Schneider EL: A simple technique for quantitation of low levels of DNA damage in individual cells. Exp Cell Res 1988, 175:184-91.

66. Muller-Pillet V, Joyeux M, Ambroise D, Hartemann P: Genotoxic activity of five haloacetonitriles: comparative investigations in the single cell gel electrophoresis (comet) assay and the ames-fluctuation test. Environ Mol Mutagen 2000, 36:52-8.

67. Olive PL, Banath JP, Durand RE: Heterogeneity in radiationinduced DNA damage and repair in tumor and normal cells measured using the "comet" assay. Radiat Res 1990, I 22:86-94.

68. Kirsch-Volders M, Sofuni T, Aardema M, Albertini S, Eastmond D Fenech M, Ishidate M Jr, Lorge E, Norppa H, Surralles J, von der Hude W, Wakata A: Report from the In Vitro Micronucleus Assay Working Group. Environ Mol Mutagen 2000, 35:167-72.

69. Lorge E, Lambert C, Gervais V, Becourt-Lhote N, Delongeas JL, Claude N: Genetic toxicity assessment: employing the best science for human safety evaluation. Part II: Performances of the in vitro micronucleus test compared to the mouse lymphoma assay and the in vitro chromosome aberration assay. Toxicol Sci 2007, 96:2 I4-7.

70. Chung WG, Roh HK, Kim HM, Cha YN: Involvement of CYP3AI, 2BI, and 2EI in C-8 hydroxylation and CYP IA2 and flavincontaining monooxygenase in $\mathbf{N}$ demethylation of caffeine; identified by using inducer treated rat liver microsomes that are characterized with testosterone metabolic patterns. Chem Biol Interact 1998, I I 3:I-14.

7I. Butler MA, Lang NP, Young JF, Caporaso NE, Vineis P, Hayes RB, Teitel $\mathrm{CH}$, Massengill JP, Lawsen MF, Kadlubar FF: Determination of CYPIA2 and NAT2 phenotypes in human populations by analysis of caffeine urinary metabolites. Pharmacogenetics 1992, 2:116-27

72. Nakajima M, Yokoi T, Mizutani M, Shin S, Kadlubar FF, Kamataki T: Phenotyping of CYPIA2 in Japanese population by analysis of caffeine urinary metabolites: absence of mutation prescribing the phenotype in the CYPIA2 gene. Cancer Epidemiol Biomarkers Prev 1994, 3:413-21.

73. Compagne Nationale Logements: Etat de la qualité de l'air dans les logements français. Rapport final [http://khe ops.champs.cstb.fr/oqai/userdata/documentation/document [33.pdf]

74. Kassie F, Parzefall W, Knasmuller S: Single cell gel electrophoresis assay: a new technique for human biomonitoring studies. Mutat Res 2000, 463:|3-3|

75. Vineis $P$, Husgafvel-Pursiainen K: Air pollution and cancer: biomarker studies in human populations. Carcinogenesis 2005 , 26:1846-55

76. Godschalk RW, Van Schooten FJ, Bartsch H: A critical evaluation of DNA adducts as biological markers for human exposure to polycyclic aromatic compounds. Biochem Mol Biol 2003, 36:I-II.

77. Phillips DH, Hewer A, Arlt VM: 32P-postlabeling analysis of DNA adducts. Methods Mol Biol 2005, 291:3-12.

78. Sousa J, Nath J, Tucker JD, Ong TM: Dietary factors affecting the urinary mutagenicity assay system. I. Detection of mutagenic activity in human urine following a fried beef meal. Mutat Res 1985, 149:365-74.

\section{Pre-publication history}

The pre-publication history for this paper can be accessed here:

http://www.biomedcentral.com/1471-2407/8/67/prepub
Publish with Bio Med Central and every scientist can read your work free of charge

"BioMed Central will be the most significant development for disseminating the results of biomedical research in our lifetime. "

Sir Paul Nurse, Cancer Research UK

Your research papers will be:

- available free of charge to the entire biomedical community

- peer reviewed and published immediately upon acceptance

- cited in PubMed and archived on PubMed Central

- yours - you keep the copyright

Submit your manuscript here:

http://www.biomedcentral.com/info/publishing_adv.asp
BioMedcentral 